\title{
The Influence of Cooperative Expenses on Profitability at KPRI colleges in Makassar City
}

\author{
M. Yusuf A. Ngampo, Sahade \\ Accounting education, Universitas Negeri Makassar, Indonesia \\ Email: yusufngampo@gmail.com
}

\begin{abstract}
This study aims to determine the effect of cooperative burden on profitability at the Cooperative Employees of the Republic of Indonesia (KPRI) of Higher Education in Makassar City. The population of this research is all KPRI Universities in Makassar City, while the sample in this study is KPRI Universities in Makassar City which have financial reports for the last five years (2015-2019). Data collection was carried out using documentation techniques. Data analysis was performed using simple regression analysis techniques, correlation coefficient, and t-test. The results showed that an increase in the cooperative burden on the KPRI of Higher Education in Makassar City would result in a decrease in profitability at the KPRI. Vice versa, if the burden of cooperatives has decreased, the profitability of the KPRI of Higher Education in Makassar City will increase. This can occur because the operating expense is one of the deductions from the income in the KPRI to generate SHU. So that if the cooperative load is in a small amount, the resulting SHU is quite large.
\end{abstract}

Keywords: Beban perkoperasian, rentabilitas koperasi

\section{INTRODUCTION}

The business world from year to year is growing rapidly which is filled with various kinds of goods and services (Papilaya et al., 2015; Rengifurwarin et al., 2018; Souisa et al., 2019a; Zainal et al., 2018). Competition is getting tougher and consumers are increasingly critical. Social and economic conditions are also increasingly developing, technological problems today are a very determining factor, various regulations must also be considered. The development of the business world in the territory of the Republic of Indonesia causes companies in their operations to be required to participate in the success of national development, in this case the government is trying to create a better business climate. The creation of a business climate is intended so that entrepreneurs can play an active role in national development (Jufri et al., 2018; A. Syam et al., 2018; H. Syam et al., 2018).

The task of the Government in building and developing cooperatives as a business entity as well as a people's economic movement is to create cooperatives that are professionally managed by applying the principles of openness, transparency and accountability that can be recognized, accepted and trusted, both by members in particular and by the wider community in general (Akib et al., 2019; Ismail et al., 2016). One indicator of the implementation of these principles is through correct and orderly accounting. Because cooperatives have an identity, the application of accounting and the submission of financial reports also shows specificity compared to the accounting and financial reports of other business entities in general (Achtenhagen, 2017; Boohene et al., 2019; Sofyan et al., 2020; Souisa et al., 2019b).

Cooperative financial reports provide information regarding the condition, performance and changes in the financial position of cooperatives, which are useful for making strategic decisions for cooperative development (Lins et al., 2017; Mcguire et al., 1988; Rachman et al., 2017; Sodeyfi, 
2016; Yusoff et al., 2013). This guideline is a refinement of the previous Indonesian Cooperative Accounting General Guidelines, which contains the practice of applying accounting to cooperatives by taking into account changes in the development of Financial Accounting Standards which refer to international financial reports (International Financial Reporting Standard or IFRS). Financial Accounting Standards Board, Indonesian Institute of Accountants on April 8, 2011 issued a Statement of Financial Accounting Standard Revocation 8 (PPSAK 8) on the revocation of Financial Accounting Standard Statement 27 (PSAK 27) concerning Cooperative Accounting.

Financial accounting standards that refer to IFRS are grouped into 2 (two) groups, namely the Entity Financial Accounting Standards without Public Accountability (SAK ETAP) and General Financial Accounting Standards (SAK Umum). Considering that so far cooperatives are included in entities without public accountability, they apply cooperative accounting with SAK ETAP. This guideline establishes the form, content of presentation and disclosure of cooperative financial reports for the internal benefit of cooperatives and other parties as users of cooperative financial reports. This guideline is a reference that must be adhered to by cooperatives and officials in providing guidance in preparing financial reports.

Every business entity, including a cooperative, always tries to keep running and growing and developing to achieve the goals to be achieved. The ability of a business entity including a cooperative to manage all its potential in an effort to earn a profit is fundamental. In achieving this goal, every business entity in carrying out its activities is expected to be able to obtain maximum profit, where the ability of the business entity to earn profits will determine the survival of the company in the future. To achieve maximum profit, the company must operate effectively and efficiently. This condition can be achieved if company leaders can implement management functions properly. In addition, it must also be supported by skilled human resources and experts in their respective fields.

A cooperative that has the main goal of making welfare for its members, one of which is to achieve this is an increase in the remaining business results (SHU) for each period, so that the remuneration for members will increase. The amount of SHU can be obtained with a reduction between the results of the business in the form of income or sales with expenses that have been incurred in a period. The higher the income or sales compared to the expenses that have been incurred, the higher the SHU obtained, and vice versa. Cooperative accounting treatment requires a separation between operating expenses and operating expenses at the time of financial reporting.

Operating expenses are expenses related to cooperative movements and are not related to business activities. Remaining Operating Results (SHU) shows the difference between the income received during a certain period and the economic sacrifices incurred to obtain that income. The operating expenses referred to consist of selling expenses and general and administrative expenses. Meanwhile, expenses included in cooperatives include training expenses for members, expenses for developing members' businesses, and expenses for cooperative movements.

Cooperatives in the city of Makassar, especially the Koperasi Pegawai Republik Indonesia (KPRI), or often referred to as Koperasi Pegawai Negeri (KPN), are based on data obtained from the Makassar City Cooperatives and SME Service, totaling 200 cooperatives. Among them are KPRI Perguruan Tinggi, with a total of 5 (five) cooperatives, namely: KPRI UNM, KPN UNHAS, KPN Akper Angin Mamiri, KPN Almuawanah IAIN Alauddin and KPN Perintis (Ujung Pandang State Polytechnic). Of the 5 cooperatives, only 2 (three) cooperatives reported the results of the RAT during 2015-2019, namely KPRI UNM, and KPN Perintis (Source: Makassar City Cooperative and UKM Service).

Based on table 1, it can be seen that KPRI UNM has a cooperative expense from 2012-2013, an increase of $29.37 \%$, but profitability from 2013-2014 decreased by 3.99\%. Then from 2012-2013, the cooperative expense increased by $80.08 \%$ and profitability also increased $0.11 \%$. Meanwhile, for KPN Perintis, the cost of cooperatives from 2012 to 2013 increased by $70.00 \%$ and profitability 
decreased by $0.20 \%$. Then in 2013-2014 there was a decrease in cooperative expenses by $80.00 \%$ and profitability increased by $6.20 \%$.

For more details, the following data are obtained about cooperative expenses and the ability to produce SHU (profitability) at the KPRI of Higher Education in Makassar City, namely:

Table 1. Operational Expenses that have been issued and Profitability of Higher Education KPRI in Makassar City 2012-2014

\begin{tabular}{lrrrrrrr}
\hline \multicolumn{1}{c}{ KPRI } & \multicolumn{3}{c}{$\begin{array}{c}\text { Operating Expenses } \\
\text { (Rp. 000.000) }\end{array}$} & \multicolumn{3}{c}{$\begin{array}{c}\text { Rentability } \\
(\%)\end{array}$} \\
\cline { 2 - 8 } & 2012 & 2013 & 2014 & 2012 & 2013 & 2014 \\
\hline KPRI UNM & 111 & 378 & 472 & 5,96 & 1,97 & 2,01 \\
KPN PERINTIS & 2,1 & 3 & 2,4 & 16,7 & 16,5 & 22,7
\end{tabular}

Source: Department of Cooperatives and SMEs in Makassar City 2018

Based on the data above, the higher the cooperative load, the lower the profitability, and the lower the cooperative load, the higher the profitability to be obtained. Based on the above background, the formulation of the problem in this study is: "how much influence is the burden of cooperatives on profitability in KPRI Perguruan Tinggi in Makassar City?".

\section{METHOD}

This research was conducted to determine how much influence the cooperative burden has on the profitability of the KPRI of Higher Education in Makassar City. The population and sample in this study were all KPRI Higher Education in Makassar City and the sample was Higher Education KPRI in Makassar City, including KPRI UNM, KPN UNHAS, and KPN Perintis which had reported RAT results for 2015-2019 respectively in Office of Cooperatives and Micro, Small and Medium Enterprises in Makassar City.

The types and sources of data used in this research are quantitative data which are sourced from reports on business results. Meanwhile, the data source is secondary data concerning financial reports. To test and prove the hypothesis, simple linear regression data analysis techniques, correlation coefficient, and t-test were used. However, before analyzing the data, data processing was conducted on the variables in this study, namely the cooperative burden and profitability.

Calculating cooperative expenses consists of members 'training expenses, members' business development expenses, contribution expenses for cooperative movements, and other expenses related to cooperative movements other than cooperative business activities. Meanwhile, to calculate profitability, namely using the ratio of return on equity or ROE (Return on equity) with the following formula according to (Riyanto, 2001).

$$
\text { Own Capital Profitability }=\frac{\text { Net Profit After Tax }}{\text { Owner's equity }} \times 100 \%
$$

S Furthermore, to determine the effect of cooperative load on cooperative profitability, statistical analysis is used, namely simple linear regression analysis, correlation coefficient, t-test.

\section{RESULTS AND DISCUSSION}

For each load that has been issued in each KPRI is different, however the authors adjust the expenses included in the operating expenses according to the guidelines of PSAK No. 27 concerning cooperative accounting. PSAK No. 27 concerning cooperative accounting, explains that, "cooperative expenses are expenses in connection with the cooperative movement and are not related to 
cooperative business activities". Therefore, the following will describe the burdens included in the cooperative expenses for each College KPRI in Makasssar City.

Table 2. Operational Expenses of each Higher Education Cooperative in Makassar City for the last 5 (five) years 2015-2019 (Rp. 000)

\begin{tabular}{lrrrr}
\hline KPRI & Years & \multicolumn{1}{c}{$\begin{array}{c}\text { Operating } \\
\text { Expenses }\end{array}$} & $\begin{array}{c}\text { The increase } \\
\text { decrease }\end{array}$ & $\begin{array}{c}\text { Development } \\
(\%)\end{array}$ \\
\hline UNM & 2015 & 172.191 & - & - \\
& 2016 & 851.759 & 679.568 & 394,66 \\
& 2017 & 1.093 .712 & 241.953 & 28,41 \\
& 2018 & 1.406 .189 & 312.477 & 28,57 \\
UNHAS & 2019 & 1.842 .635 & 436.446 & 31,04 \\
& 2015 & 7.5350 & - & - \\
& 2016 & 15.752 & 8.217 & 109,05 \\
& 2017 & 5.518 & $(10.234)$ & $-64,97$ \\
Perintis & 2018 & 97.562 & 92.044 & 1668,07 \\
& 2019 & 71.205 & $(26.357)$ & $-27,02$ \\
& 2015 & 2.687 & - & - \\
& 2016 & 3.514 & 826 & 30,75 \\
& 2017 & 4.898 & 1.384 & 39,39 \\
& 2018 & 9.058 & 4.159 & 84,92 \\
& 2019 & 10.107 & 1.048 & 11,58 \\
\hline
\end{tabular}

Source: Department of Cooperatives and SMEs in Makassar City 2019

Table 2 shows that the cooperative expenses of the three KPRIs, namely KPR UNM and KPRI Perintis, experienced a very large increase in five years, especially KPRI UNM from 2015-2019, the increase reached Rp. 679,562,074, - or 394.66 percent. Meanwhile, KPRI Perintis saw a significant increase in 2017-2018, namely Rp. 4,159,893, - or 84.92 percent.

Furthermore, profitability is the company's ability to achieve profit (SHU) as a result of using a certain amount of capital in the company. In this study, the profitability used is the return on equity (ROE). ROE can be obtained by comparing SHU after tax with own capital.

Description of the condition and development of higher education KPRI profitability, which is measured using its own capital profitability. From table 3, it can be seen that the increase and decrease in the profitability of higher education KPRIs in Makassar City, this is due to the changing SHU, sometimes increasing and decreasing drastically, so that the profitability fluctuates, even though the capital itself has increased every year. A drastic decrease in profitability can be seen, at the 2015-2016 KPRI UNM, namely $88.25 \%$ then an increase of $10.08 \%$ in 2018-2019. In addition, KPN UNHAS decreased profitability by an average of $24.67 \%$ in 2015-2017. But in 2017-2019 there was a good increase in the previous few years by an average of $8.55 \%$. Whereas KPN Perintis profitability that occurred during $2015-2019$ decreased profitability in $2015-2016$ by $54.11 \%$, but in 2016-2017 there was a very high increase in profitability, reaching $600.40 \%$ or an increase of 6 times from the previous year, this was due to an increase in SHU from 2016 only amounting to IDR 4,704,268, - in 2017 SHU increased to IDR 36,156,596, - then in 2018-2019 there was an average decrease of $23.86 \%$.

Based on these data, it can be concluded that the increase in profitability is a result of the increase in SHU even though the capital itself does not increase as much as the increase in SHU, and 
vice versa if the profitability decreases. Therefore, high profitability is also a high SHU achievement in a cooperative, especially the College KPRI in Makassar City.

The condition of profitability at Higher Education KPRI in Makassar City during 2015-2019 data is seen in the following table:

Table 3. Conditions of Profitability at Higher Education KPRI in Makassar City for the last 5 (five) years $(2015-2019)$

\begin{tabular}{lrrrr}
\hline KPRI & Years & \multicolumn{1}{c}{$\begin{array}{c}\text { SHU } \\
\text { (Rp.000) }\end{array}$} & $\begin{array}{c}\text { Owner's equity } \\
\text { (Rp.000) }\end{array}$ & $\begin{array}{c}\text { ROE } \\
(\%)\end{array}$ \\
\hline UNM & 2015 & 590.192 & 4.144 .711 & 14,24 \\
& 2016 & 86.210 & 5.152 .093 & 1,67 \\
& 2017 & 99.142 & 7.916 .170 & 1,25 \\
& 2018 & 128.884 & 10.192 .488 & 1,26 \\
UNHAS & 2019 & 181.003 & 13.003 .183 & 1,39 \\
& 2015 & 681.842 & 1.541 .329 & 44,24 \\
& 2016 & 854.350 & 1.940 .318 & 34,03 \\
& 2017 & 947.876 & 2.857 .880 & 35,17 \\
Perintis & 2018 & 698.621 & 1.962 .431 & 36,04 \\
& 2019 & 895.302 & 2.484 .530 & 4,75 \\
& 2015 & 8.475 & 178.397 & 2,18 \\
& 2016 & 4.704 & 215.801 & 15,27 \\
& 2017 & 36.156 & 236.811 & 8,80 \\
\hline
\end{tabular}

Source: Department of Cooperatives and SMEs in Makassar City 2019

Meanwhile, the development of profitability at Higher Education KPRI in Makassar City during the last five years (2015-2019) can be seen in table 4.

Table 4. Development of Profitability at Higher Education KPRI in Makassar City for the last 5 (five) years (2015-2019)

\begin{tabular}{lrrrr}
\hline KPRI & Years & \multicolumn{1}{c}{$\begin{array}{c}\text { ROE } \\
(\%)\end{array}$} & $\begin{array}{l}+/- \\
(\%)\end{array}$ & $\begin{array}{r}\text { Development } \\
(\%)\end{array}$ \\
\hline UNM & 2015 & 14,24 & $-12,57$ & - \\
& 2016 & 1,67 & $-0,42$ & $-10,21$ \\
& 2017 & 1,25 & 0,01 & 2,43 \\
& 2018 & 1,26 & 0,13 & 0,44 \\
UNHAS & 2019 & 1,39 & - & $-0,47$ \\
& 2015 & 44,24 & $-88,25$ & $-24,67$ \\
& 2016 & 44,03 & $-25,15$ & 7,33 \\
& 2017 & 33,17 & 0,97 & 1,22 \\
Perintis & 2018 & 35,60 & 10,08 & - \\
& 2019 & 36,04 & $-54,11$ \\
& 2015 & 4,75 & $-2,57$ & 600,40 \\
& 2016 & 2,18 & 13,09 & $-30,16$ \\
& 2017 & 15,27 & $-4,60$ & $-17,50$ \\
\hline
\end{tabular}




\section{Source: Department of Cooperatives and SMEs in Makassar City 2019}

Based on the condition of the cooperative load and profitability which have been analyzed separately, to prove whether there is an influence statistically presented data for analysis of the two variables, both cooperative load as the independent variable symbolized (X) and profitability (ROE) as the dependent variable symbolized $(\mathrm{Y})$ each of these variables is measured using a ratio by ignoring the negative value (-) for each value. Then the data in the table will be processed through simple regression analysis with the help of SPSS 16 (Statistical Product and Service Solutions). The two variables to be analyzed are presented in table 5.

Table 5. Cooperative Expenses (X) and Profitability (Y) at Higher Education KPRI in Makassar City during 2015-2019.

\begin{tabular}{lrrr}
\hline KPRI & Years & $\begin{array}{c}\text { B. P.Kop }(\mathrm{X}) \\
(\%)\end{array}$ & $\begin{array}{c}\text { ROE (Y) } \\
(\%)\end{array}$ \\
\hline UNM & 2015 & 394,66 & - \\
& 2016 & 28,41 & $-0,21$ \\
& 2017 & 28,57 & $-10,86$ \\
& 2018 & 31,04 & 2,43 \\
UNHAS & 2019 & - & 0,44 \\
& 2015 & 109,05 & - \\
& 2016 & $-64,97$ & $-0,47$ \\
& 2017 & 1668,07 & $-24,67$ \\
Perintis & 2018 & $-27,02$ & 7,33 \\
& 2019 & - & 1,22 \\
& 2015 & 30,75 & - \\
& 2016 & 39,39 & $-54,11$ \\
& 2017 & 84,92 & 600,40 \\
& 2018 & 11,58 & $-30,16$ \\
& 2019 & & $-17,50$ \\
\hline
\end{tabular}

Source: Processed data, 2020

The data is processed using simple linear regression analysis, which results in a linear equation $\mathrm{Y}=44.238-0.024(\mathrm{X})$. From the regression equation, the constant value (a) is 44.238, indicating that when KPRI College in Makassar City does not have a cooperative burden or $\mathrm{X}=0$, then the profitability obtained by the KPRI of Higher Education in Makassar City will increase by $44.238 \%$. But if the cooperative expenses incurred by the KPRI of Higher Education in Makassar City are in large numbers, then the profitability obtained will reach a low percentage $(\%)$. While the value of $b$ (coefficient of linear regression direction) is $-0.024 \mathrm{X}$. This shows that each additional cooperative expense incurred by the KPRI of Higher Education in Makassar City of Rp. 100.00 will automatically result in a decrease in profitability at the College KPRI by $2.4 \%$. Or at every increase in the cooperative expense at the KPRI of Higher Education in Makassar City by 1 (one) unit of rupiah, the profitability will automatically decrease by $0.024 \%$.

Based on the results of the simple linear regression equation, it can be concluded that the increase in cooperative expenses incurred will result in a decrease in profitability in the KPRI. Vice versa, if the burden of cooperatives has decreased, the profitability of the KPRI of Higher Education in Makassar City will increase. This can occur because the operating expense is one of the deductions from the income to generate SHU. So that if the cooperative load is in a small amount, the resulting SHU is quite large. The relation with profitability is that the higher the SHU, the 
profitability will increase, because high profitability is a symbol that the SHU generated is also in a high condition.

Furthermore, to determine the degree of influence of the two variables, a correlation coefficient test ( $r$ ) was carried out. The magnitude of the correlation coefficient $(r)$ is an indicator that shows the degree of relationship between cooperative load (X) and profitability (Y) of Higher Education KPRI in Makassar City. The correlation coefficient value obtained is -0.065 which is negative. This shows that the relationship (correlation) between cooperative load and profitability has a negative correlation, meaning that the higher the cooperative load, the lower the profitability, conversely the lower the cooperative load, the higher the profitability. Furthermore, to determine the degree of the relationship between cooperative burden and profitability at KPRI colleges in Makassar City, a correlation interpretation is used, as suggested by Sugiyono (2009: 214). Based on the table, the correlation coefficient (r) of 0.065 is in the range of $0.00-0.199$ or at a very low level of relationship. So that the cooperative burden and profitability at the KPRI of Higher Education in Makassar City has a very low correlation.

Meanwhile, to determine whether there is an effect of the two variables, t-test analysis is carried out. The presentation of the proposed hypothesis is that if tcount>ttable, it can be said that the cooperative burden (X) affects profitability (Y) or the hypothesis is accepted, and vice versa if tcount $<$ ttable, then the hypothesis is rejected. The results of the t-test analysis, the value of $t=0.205$ using the significant level $\alpha=0.05$, then the determination of the correlation can be calculated by $\mathrm{dk}$ $=\mathrm{n}-\mathrm{m}-1(12-1-1)$, so that $\mathrm{dk}=10$ and from these results obtained the value of $\mathrm{t}$ table $=1,812$. These results indicate that tcount <ttable, which is $0.205<1.812$, while the significance value is $0.842>$ 0.05 . So that the hypothesis is rejected or the burden of cooperatives has no effect on profitability at the KPRI of Higher Education in Makassar City.

Based on these results, it is explained that this is due to the increase and decrease in the percentage value of the cooperative load which is unstable and or not in accordance with the theory, if the cooperative load has increased, the profitability will decrease and if the cooperative load has decreased, the profitability will increase. The increase or decrease in question is unstable and or not in accordance with the theory, where there is a possibility that cooperative expenses are included in the financial statements combined with operating costs, while according to PSAK 27 (2009: 27.4) that, "operating expenses are expenses related to cooperative movements and not related to business activities ". This can be seen in 2017 for each cooperative. KPRI UNM cooperative expenses in that year increased by $28.41 \%$ (2016-2017) while profitability decreased by $-10.86 \%$. When compared with the increase in cooperative expenses (2015-2016) it reached $394.66 \%$ with a decrease in profitability of only $-0.21 \%$. This occurred due to the high cost of cooperatives in 2017 compared to 2016. Meanwhile, the KPN UNHAS cooperative expense in 2017 experienced a decrease of $-64 \%$ with a decrease in profitability of $-24.67 \%$. The decrease in profitability does not mean that the SHU decreases, but it can occur due to the increase in SHU and own capital at KPN UNHAS, even though the increase (SHU) is low. Furthermore, the KPN Perintis cooperative expense in 2017 increased by $39.39 \%$ (2016-2017) with the profitability reaching a fairly high increase, namely $600.40 \%$. The high profitability was due to the increase in SHU, even though the cooperative expense had increased, but it was supported by the increase in sales in 2017 which reached Rp. 198,268,362.00 compared to only Rp. So it can be concluded that an increase in cooperative expenses will result in a decrease in profitability. However, if the cooperative expense has decreased, the profitability will increase or decrease, but the decline in profitability does not explain that SHU has decreased, but the SHU achievement is low even though there is an increase . Therefore, in this study, the cooperative burden on profitability has no effect on the KPRI of Higher Education in Makassar City.

\section{CONCLUSION}

The analysis of the cooperative load ratio shows that the cooperative expenses of the three KPRIs, namely KPR UNM, UNHAS and KPRI Perintis have increased significantly over the past 
five years, especially KPRI UNM from 2015-2019. Meanwhile, KPRI Perintis saw a significant increase in 2017-2018. The results of the analysis of higher education KPRI profitability ratios, which are measured using their own capital returns, show an increase and decrease in higher education KPRI profitability in Makassar City, this is because SHU changes, sometimes increases and decreases drastically, so that profitability changes. -changed, although the capital itself has increased every year. The increase in profitability is the result of an increase in SHU even though the capital itself does not increase as much as the increase in SHU, and vice versa if the profitability decreases. Therefore, high profitability is also a high SHU achievement in a cooperative, especially the College KPRI in Makassar City.

\section{REFERENCES}

Achtenhagen, L. (2017). Media Entrepreneurship-Taking Stock and Moving Forward. JMM International Journal on Media Management, 19(1), 1-10. https://doi.org/10.1080/14241277.2017.1298941

Akib, H., Wagianto, E., Daraba, D., Farida, U., \& Niswaty, R. (2019). Shift-share analysis of the development of local competence as a basis for interregional cooperation in West Sulawesi Province, Indonesia. Journal of Legal, Ethical and Regulatory Issues, 22(1).

Boohene, R., Gyimah, R. A., \& Osei, M. B. (2019). Social capital and SME performance: the moderating role of emotional intelligence. Journal of Entrepreneurship in Emerging Economies. https://doi.org/10.1108/JEEE-10-2018-0103

Ismail, A., Sulur, A. H., Akib, H., \& Salam, R. (2016). Snapshot of Society Social-Economic Welfare based on Human Development Index in Polewali Mandar Regency, Indonesia. International Conference on Public Organization VI (ICONPO VI), 847-858.

Jufri, M., Akib, H., Ridjal, S., Sahabuddin, R., \& Said, F. (2018). Improving attitudes and entrepreneurial behaviour of students based on family environment factors at vocational high school in Makassar. Journal of Entrepreneurship Education, 21(2).

Lins, K. V, Servaes, H., \& Tamayo, A. (2017). Social capital, trust, and firm performance: The value of corporate social responsibility during the financial crisis. The Journal of Finance, 72(4), $1785-1824$.

Mcguire, J. B., Sundgren, A., Schneeweis, T., \& Mcguire, J. B. (1988). Corporate Social Responsibility and Financial Performance. Academy of Management Journal, 31(4), 854-872.

Papilaya, J., Soisa, T. R., \& Akib, H. (2015). The influence of implementing the strategic policy in creating business climate, business environment and providing support facilities towards business empowerment on small medium craft enterprises in Ambon Indonesia. International Review of Management and Marketing, 5(2).

Rachman, E., Nawawi, J., Arismunandar, Kasmawati, A., \& Akib, H. (2017). Autonomy of private higher education management: Financial accountability perspective. International Journal of Economic Research, 14(12), 175-185.

Rengifurwarin, Z. A., Akib, H., Jasruddin, \& Salam, R. (2018). Snapshot of public service quality in the center for integrated business service (CIBS), cooperative micro small and medium enterprises (CMSME), Maluku province, Indonesia. Journal of Entrepreneurship Education, 21(3).

Riyanto, B. (2001). Dasar-dasar pembelanjaan perusahaan.

Sodeyfi, S. (2016). Review of literature on the nexus of financial leverage, product quality, \& business conditions. Journal of Economic \& Management Perspectives, 10(2), 146-150.

Sofyan, Y., Haris, H., Akib, H., Gani, H. A., \& Nuralim, M. (2020). Cooperative Establishment Service System in the Cooperative Office and Small and Medium Enterprises (UKM) Makassar City. 226(Icss), 1157-1160. https://doi.org/10.2991/icss-18.2018.243 
Souisa, W., Musa, C. I., Akib, H., Anshari, \& Bado, B. (2019a). Determinats of the performance of cooperative manager in ambon city, indonesia. Journal of Entrepreneurship Education, 22(1).

Souisa, W., Musa, C. I., Akib, H., Anshari, \& Bado, B. (2019b). Determinats of the performance of cooperative manager in ambon city, indonesia. Journal of Entrepreneurship Education, 22(1).

Syam, A., Hasbiah, S., Yunus, M., \& Akib, H. (2018). Determinants of entrepreneurship motivation for students at educational institution and education personnel in Indonesia. Journal of Entrepreneurship Education, 21(2).

Syam, H., Akib, H., Patonangi, A. A., \& Guntur, M. (2018). Principal entrepreneurship competence based on creativity and innovation in the context of learning organizations in Indonesia. Journal of Entrepreneurship Education, 21(Special Issue).

Yusoff, H., Mohamad, S. S., \& Darus, F. (2013). The Influence of CSR Disclosure Structure on Corporate Financial Performance: Evidence from Stakeholders' Perspectives. Procedia Economics and Finance, 7(Icebr), 213-220. https://doi.org/10.1016/s2212-5671(13)00237-2

Zainal, H., Parinsi, W. K., Hasan, M., Said, F., \& Akib, H. (2018). The influence of strategic assets and market orientation to the performance of family business in Makassar City, Indonesia. Academy of Strategic Management Journal, 17(6). 